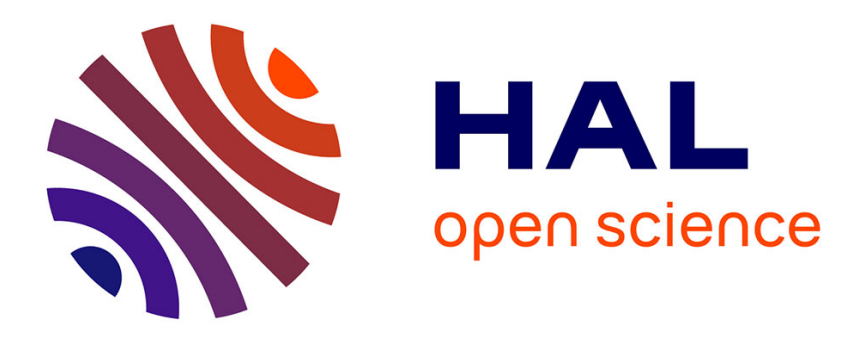

\title{
Dietary calcium and phosphorus manipulations in thyroparathyroidectomized pregnant rats and fetal liver glycogen stores \\ J.-M. Garel, M. Gilbert
}

\section{- To cite this version:}

J.-M. Garel, M. Gilbert. Dietary calcium and phosphorus manipulations in thyroparathyroidectomized pregnant rats and fetal liver glycogen stores. Reproduction Nutrition Développement, 1981, 21 (6A), pp.969-977. hal-00897913

\section{HAL Id: hal-00897913 https://hal.science/hal-00897913}

Submitted on 1 Jan 1981

HAL is a multi-disciplinary open access archive for the deposit and dissemination of scientific research documents, whether they are published or not. The documents may come from teaching and research institutions in France or abroad, or from public or private research centers.
L'archive ouverte pluridisciplinaire HAL, est destinée au dépôt et à la diffusion de documents scientifiques de niveau recherche, publiés ou non, émanant des établissements d'enseignement et de recherche français ou étrangers, des laboratoires publics ou privés. 
Reprod. Nutr. Dévelop., 1981, 21 (6A), 969-977.

\title{
Dietary calcium and phosphorus manipulations in thyroparathyroidectomized pregnant rats and fetal liver glycogen stores
}

\author{
par J.-M. GAREL, M. GILBERT * \\ Physiologie du Développement, Université Pierre et Marie-Curie, \\ 9, quai Saint-Bernard, 75230 Paris cedex 05, \\ * Laboratoire de Physiologie du Développement, Collège de France, \\ place M. Berthelot, 75231 Paris cedex 05.
}

Summary. Low levels of blood glucose and hepatic glycogen in thyroparathyroidectomized (TPTX) mothers and their fetuses have been shown to increase after vitamin $D_{3}$ metabolite injection to the mothers when their plasma calcium is low or slightly elevated. To determine the putative role of calcium in these experiments, we elevated TPTX maternal plasma calcium by calcium supplementation or dietary calcium manipulations. Four hours later, glucose administration to those mothers at day 21.5 of gestation increased hepatic glycogen concentrations as well as ${ }^{14} \mathrm{C}$-glucose incorporation in hepatic glycogen in both mothers and fetuses. In contrast, the simultaneous treatment of TPTX mothers with calcium and glucose at day 21.5 of gestation induced marked elevations in fetal and maternal blood glucose levels $4 \mathrm{~h}$ later without changing hepatic glycogen stores. In fact, ${ }^{14} \mathrm{C}$-glucose incorporation decreased in fetal liver glycogen. Similar results were obtained in chronic experiments involving calcium supplementation with calcium lactate or the use of a calcium-rich diet. Blood glucose levels were normalized, whereas hepatic glycogen levels were unchanged in both mothers and fetuses. On the contrary, the use of a low phosphorus diet (known to increase 1,25-dihydroxyvitamin $D_{3}$ production) in TPTX mothers increased both blood glucose and hepatic glycogen concentrations in mothers and fetuses. These data suggest that 1,25-dihydroxyvitamin $D_{3}$ in TPTX mothers may act in two ways : (i) by increasing plasma calcium which would partly explain the normoglycemia, and (ii) by inhibiting the glycogenolytic effect of calcium and thus allowing hepatic glycogen stores to increase

\section{Introduction.}

Rat fetuses from thyropa rathyroidectomized (TPTX) mothers are known to exhibit decreased values of blood glucose and hepatic glycogen stores (Porferfield, Whittle and Hendrich, 1975 ; Garel and Gilbert, 1978), and grafting one parathyroid gland or injecting vitamin $D_{3}$ metabolites to TPTX mothers restores those levels in the fetus (Gilbert, Besnard and Garel, 1980). This increase in both the fetal blood glucose and the liver glycogen stores occurs in the presence of a low but slightly elevated level of maternal plasma calcium (Garel, Gilbert and Besnard, 1981). To determine the putative role of maternal plasma calcium in the normalization of fetal blood glucose and in 
the marked improvement of fetal liver glycogen stores, we attempted to correct the plasma calcium level in TPTX mothers by acute experimentation involving calcium injection and by chronic experimentation using dietary calcium and phosphorus manipulations.

\section{Material and methods.}

Experimental procedures. - Unless otherwise noted, pregnant female rats of the Wistar strain were fed a commercial diet (UAR 103) and water ad libium. The calcium, phosphorus and magnesium contents of the diets were $0.92,0.92$ and 0.15 p. 100, respectively. The vitamin $D$ content was $4000 \mathrm{IU} / \mathrm{kg}$. Gestational age was determined from the estimated time of ovulation. When a female rat was caged with a male between 17.00 and $09.00 \mathrm{~h}$, ovulation was estimated to have occurred at $01.00 \mathrm{~h}$. Pregnant rats were detected by palpation 12.5 days later. In our colony, parturition occurred after 22 days of gestation.

Pregnant females were TPTX by surgery under light ether anesthesia on day 12.5 of gestation.

- In the first set of experiments we studied the effects of glucose or calcium administration to TPTX mothers at day 21.5 of gestation. Group 1 TPTX mothers were given a single glucose load ( $1 \mathrm{ml}$ of 50 p. 100 glucose + a tracer dose of $U{ }^{14} \mathrm{C}$-glucose : $25 \mu \mathrm{Ci}$ ) by stomach gavage at day 21.5 of gestation and were then killed $4 \mathrm{~h}$ later. The pregnant TPTX control females were given the tracer dose of $U^{14} \mathrm{C}$-glucose $(25 \mu \mathrm{Ci})$ by stomach gavage. The administration of this pulse of radio-glucose gave an indication of hepatic glycogen metabolism.

Group 2 TPTX mothers were intraperitoneally injected with $\mathrm{CaCl}_{2}(6 \mathrm{mg} / 100 \mathrm{~g}$ of body weight) at day 21.5 of gestation and, at the same time, received a tracer dose of $\mathrm{U}{ }^{14} \mathrm{C}$-glucose $(25 \mu \mathrm{Ci})$ by stomach gavage ; they were killed $4 \mathrm{~h}$ later.

Group 3 was given ad libitum a chronic calcium supplementation (1 p. 100 calcium lactate +3 p. 100 lactose) in the drinking water from days 12.5 to 21.5 of gestation since lactose is known to increase intestinal calcium absorption (Fournier, 1954 ; Lengemann, Wasserman and Comar, 1959). These females were studied at 21.5 days of gestation.

- In the second set of experiments TPTX mothers were fed unbalanced calciumphosphorus diets. Group 1 received a diet containing 0.6 p. 100 P and 1.8 p. $100 \mathrm{Ca}$, which varied from the basal UAR diet only in its calcium and phosphorus contents. Group 2 was put on a low phosphorus diet (semi-synthetic diet UAR Ref. 212 P based on the general composition of basal diet UAR 103) containing 0.2 p. $100 P$ and $1.2 \mathrm{p} .100 \mathrm{Ca}$. The pregnant females stayed on these unbalanced diets from the day of TPTX (day 12.5 of gestation) until the end of gestation (day 21.5 stage).

With these different dietary manipulations, the weight gain and the daily food intake of the TPTX mothers were roughly similar to those of the untreated TPTX mothers. The modifications caused by TPTX in pregnant rats have already been described by Garel, Gilbert and Besnard (1981) : weight gain stopped the last two days and daily food intake decreased gradually the last 4 days of gestation. 
Assuming a similar time lapse between the last food intake and sacrifice, we killed the mothers by decapitation between 09.00 and $10.00 \mathrm{~h}$ and collected a blood sample. The maternal liver was quickly removed and stored in liquid nitrogen. The fetuses were rapidly delivered and, after cleaning the axillary region, blood was withdrawn through an incision across the axillary vessels. The fetal liver was also removed quickly and stored in liquid nitrogen. Since it has been shown that a rapid drop occurs in plasma calcium and phosphate levels soon after detachment of the fetus (Garel, 1969), a different protocol was used in the studies assaying plasma calcium and inorganic phosphorus concentrations. So, after the mother was anesthetized with ether, the fetuses were excised one by one from her well-ventilated, living body by laparotomy and hysterectomy, leaving the placental circulation intact. Fetal blood samples were taken immediately with heparinized Pasteur pipettes by section of the brachial artery. At the end of the experiments, the maternal blood was removed by intracardiac puncture.

Biochemical methods. - Plasma calcium was estimated by flame photometry (Eppendorf) and plasma inorganic phosphorus by the method of Chen, Toribara and Warner (1956). Barium hydroxide-zinc sulfate filtrates of blood were used for glucose assay using the glucose-oxidase method of Huggett and Nixon (1957). Hepatic glycogen was estimated by the method of Roehrig and Allred (1974); the frozen liver was weighed and homogenized at $0^{\circ} \mathrm{C}$ in a Potter-Elvehjem tissue homogenizer; an aliquot was incubated for $10 \mathrm{~min}$ at $55^{\circ} \mathrm{C}$ with amylo $\alpha-1,4 / \alpha-1,6$ glucosidase (Boehringer, Mannheim, W. Germany) and then treated by glucose-oxidase. When a tracer dose of the $U{ }^{14} \mathrm{C}$-glucose was administered to TPTX mothers, hepatic glycogen content and radioactivity were simultaneously determined according to the method of Chan and Exton (1976). The frozen liver was weighed and homogenized (2.5 p. 100) in bi-distilled water with a glass teflon homogenizer. $0.1 \mathrm{ml}$ of homogenate was spotted on a $2 \times 3-\mathrm{cm}$ piece of filter paper (Whatman $3 \mathrm{MM}$ chromatography paper). The papers were dropped into a beaker containing 66 p. 100 ethanol and washed 3 times $(3 \times 10 \mathrm{~min})$. They were then rinsed briefly with acetone, dried and placed in plastic tubes containing $0.4 \mathrm{ml}$ of acetate buffer $(0.05 \mathrm{M}, \mathrm{pH} 4.5), 1.6 \mathrm{ml}$ of $\mathrm{H}_{2} \mathrm{O}$ and $0.2 \mathrm{ml}$ of amylo $\alpha-1,4 / \alpha-1,6$ glucosidase ( 3 units). The fubes were put at $55^{\circ} \mathrm{C}$ for $30 \mathrm{~min}$ to allow the glycogen to hydrolize. Glucose was determined in $0.1 \mathrm{ml}$ of hydrolysate using the glucose oxidase method. One $\mathrm{ml}$ of hydrolysate was placed in a vial containing $10 \mathrm{ml}$ of scintillation liquid (PCS Amersham Searle) and radioactivity was measured in a liquid scintillation spectrometer (Nuclear Chicago Corp., Des Plaines, III.).

The results, statistically analyzed using Student's unpaired t-test to determine the significance of changes between the control and the experimental groups, were recorded as the mean \pm SEM.

\section{Results.}

- Glucose or calcium administration to TPTX mothers.

Glucose administration. - The oral administration of a single load of 50 p. 100 glucose to TPTX mothers at day 21.5 of gestation increased hepatic glycogen concen- 
trations $4 \mathrm{~h}$ later in both mothers and fetuses (table 1). Maternal and fetal blood glucose levels returned to basal values $4 \mathrm{~h}$ after stomach gavage with $1 \mathrm{ml}$ of $50 \mathrm{p} .100$ glucose. The ${ }^{14} \mathrm{C}$-glucose incorporated into hepatic glycogen increased significantly in both mothers and fetuses (table 1). The treatment did not affect plasma calcium and phosphate levels.

TABLE 1

Effects after $4 \mathrm{~h}$ of a single load of glucose given to TPTX mothers at 21.5 days of gestation

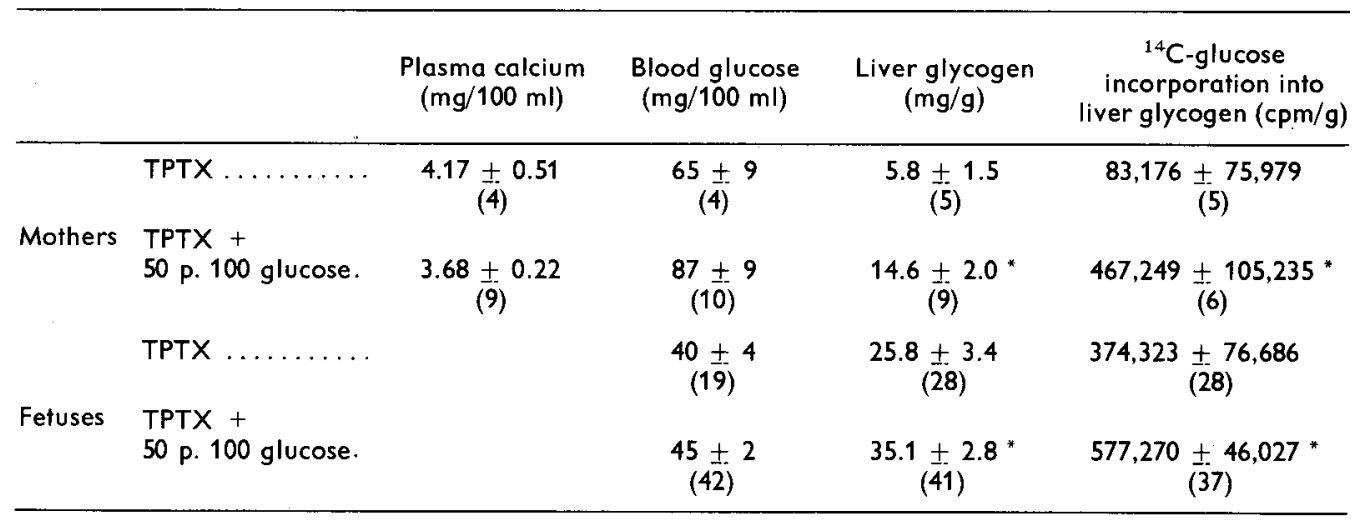

Means $\pm S E M$; the number of observations is shown in brackets. Controls (untreated TPTX) : ${ }^{14} \mathrm{C}$-glucose gavage only; Treated : ${ }^{14} \mathrm{C}$-glucose $+1 \mathrm{ml} 50$ p. 100 glucose by stomach gavage. ${ }^{*} \mathrm{P}<0.05$ from controls; no symbol : not different from controls.

Calcium administration. - A single calcium load ( $6 \mathrm{mg}$ of $\mathrm{Ca} / 100 \mathrm{~g}$ of body weight) given by IP injection significantly raised the plasma calcium level in TPTX mothers $30 \mathrm{~min}(12.82 \pm 0.66 \mathrm{mg} / 100 \mathrm{ml})$ and $4 \mathrm{~h}(7.37 \pm 0.47 \mathrm{mg} / 100 \mathrm{ml})$ later and induced a marked increase in maternal and fetal blood glucose levels (table 2). However, hepatic glycogen concentrations did not change significantly in either mothers or fetuses $4 \mathrm{~h}$ after the calcium load. In contrast, a trend to lower values was observed in the fetal liver. A significant drop of ${ }^{14} \mathrm{C}$-glucose incorporation into fetal liver glycogen occurred $4 \mathrm{~h}$ after the calcium load was given to the mother (table 2).

The repeated administration of calcium to TPTX mothers by supplementing the drinking water with calcium lactate and lactose suppressed the mortality rate at day 19.5 of gestation, but did not maintain a normal plasma calcium concentration in the mother until the last day of gestation. The maternal plasma calcium level at day 21.5 of gestation was not different from that observed in untreated TPTX mothers (table 2). This chronic calcium supplementation in TPTX mothers increased fetal weight slightly on day $\mathbf{2 1 . 5}$ of gestation, as well as maternal and fetal blood glucose levels (table 2) which were not different from those found in normal females. However, hepatic glycogen concentrations in mothers and fetuses remained at the values observed in untreated TPTX mothers (table 2). 







\section{- Unbalanced calcium-phosphorus diets in TPTX mothers.}

Effects on the mother. - A normal phosphorus diet $(0.6$ p. 100) rich in calcium (1.8 p. 100) given from day 12.5 of gestation to the end of gestation (21.5 days) to TPTX mothers improved the plasma calcium levels until day 19.5 of gestation $(9.51 \pm 0.77 \mathrm{mg} /$ $100 \mathrm{ml}$ ). The maternal plasma calcium level was not maintained through the last two days of gestation (fig. 1) since at term that value was not different from the value of the TPTX control mothers. However, plasma phosphate levels still decreased at day 21.5 of gestation (fig. 1), the lowest concentration occurring at 19.5 days $(1.21 \mathrm{mg} / 100 \mathrm{ml})$. Blood glucose levels were normalized, but hepatic glycogen stores were not significantly increased (fig. 1).

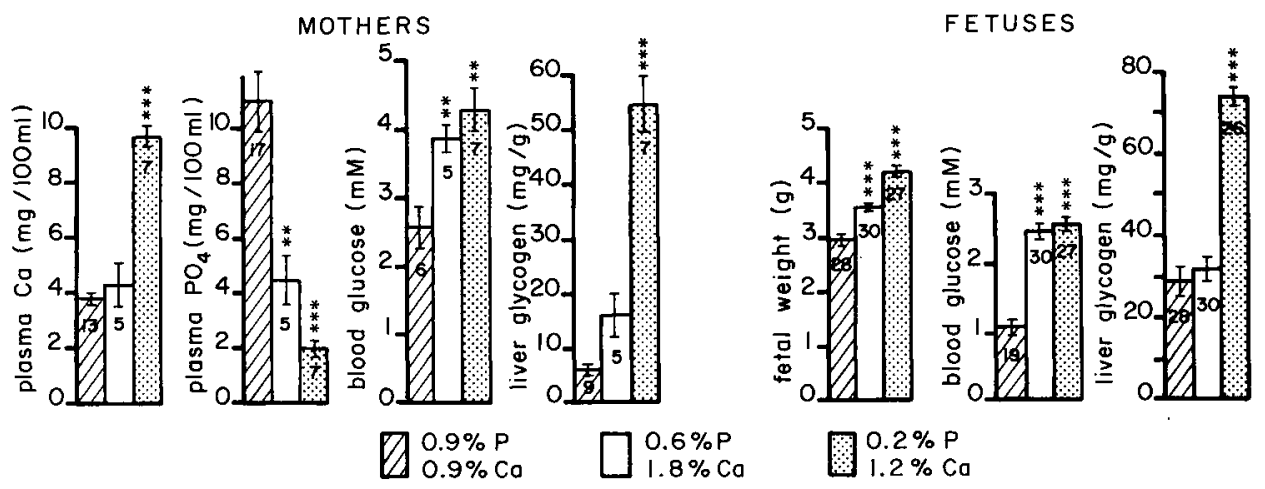

FIG. 1. - Effects at 21.5 days of gestation on TPTX mothers and their fetuses of unbalanced calciumphosphorus diets given to the mothers. Means \pm SEM; the numbers on the bars are the number of observations. ** $\mathrm{P}<0.01$ from TPTX controls $(0.9$ p. $100 \mathrm{P}, 0,9$ p. $100 \mathrm{Ca})$; *** $\mathrm{P}<0.001$ from TPTX controls.

A low phosphorus diet $(0.2$ p. 100 P, 1.2 p. $100 \mathrm{Ca})$ given to TPTX mothers raised both plasma calcium and blood glucose levels at 21.5 days of gestation in the mother (fig. 1). Those levels were not different from the levels of the normal females. The, plasma phosphate content was sharply reduced (mean value : $1.97 \pm 0.2 \mathrm{mg} / 100 \mathrm{ml}$ ), and the hepatic glycogen stores greatly enhanced (by 9-fold) at the same time (fig. 1). A maternal plasma phosphate level of $0.4 \pm 0.05 \mathrm{mg} / 100 \mathrm{ml}$ was observed at day 20.5 of gestation.

Effects on the fetus. - Fetal weight at day 21.5 of gestation was slightly improved when the TPTX mothers were fed a calcium-rich dief $(\mathrm{Ca} / \mathrm{P}: 3)$. In spite of a normal blood glucose level, the hepatic glycogen stores were not increased (fig. 1). However, fetal weight was normal until day 20.5 of gestation. Body weight and liver glycogen were greatly increased in the fetuses of TPTX mothers receiving the low phosphorus diet; blood glucose was not different from that observed in normal fetuses (fig. 1). Fetal plasma calcium concentrations were normalized at 20.5 days of gestation 
$(11.9 \pm 0.34 \mathrm{mg} / 100 \mathrm{ml})$ and fetal plasma phosphate levels remained high $(6.03 \pm 0.58 \mathrm{mg} / 100 \mathrm{ml})$ in contrast to the extremely low level of maternal plas ma phosphate $(0.4 \pm 0.58 \mathrm{mg} / 100 \mathrm{ml})$ observed at that stage.

\section{Discussion.}

From the present results if appears that an acute load of glucose given to TPTX mothers at day 21.5 of gestation increases both maternal and fetal liver glycogen stores $4 \mathrm{~h}$ later as well as ${ }^{14} \mathrm{C}$-glucose incorporation in liver glycogen. In contrast, the simultaneous treatment of TPTX mothers with calcium and glucose did not change hepatic glycogen stores $4 \mathrm{~h}$ later in either mothers or fetuses. In fact, ${ }^{14} \mathrm{C}$-glucose incorporation was clearly reduced in fetal liver glycogen. One of the unexpected results of this acute administration to TPTX mothers was the marked increase in blood glucose levels in both mothers and fetuses. Chronic calcium administration to TPTX mothers (as calcium lactate or in a calcium-rich diet) normalized the blood glucose levels in mothers and fetuses without changing the hepatic glycogen stores in either one. In all cases, when maternal plasma calcium was raised in TPTX mothers by the use of calcium, the results were similar in mothers and fetuses. Thus, the normalization of plasma calcium concentration in the mother may partly explain the recovery of the blood glucose levels. It has been previously shown that correcting maternal hypoparathyroidism by grafting one parathyroid gland or by injecting vitamin $D_{3}$ metabolites to TPTX mothers restores fetal blood glucose to normal and induces a twofold increase in fetal liver glycogen stores (Garel, Gilbert and Besnard, 1979 ; Gilbert, Besnard and Garel, 1980). These effects are not due to the nutritional status of the mother (Gilbert, Besnard and Garel, 1980) ; the fact that fetal liver glycogen stores are unchanged after maternal dietary restriction is well known. It is difficult to explain our results, but some speculation can be made. The parathyroid hormone has been shown to stimulate hepatic glucose production and gluconeogenesis in vitro and in vivo (Moxley et al., 1974 ; Hruska et al., 1979). The effect observed in vivo is specific to the entire molecule (PTH1-84) since the synthetic $\mathrm{NH}_{2}$-terminal tetracontapeptide (PTH 1-34) has no effect (Hruska et al., 1979) ; however both molecules are equally effective in raising plasma calcium. Thus, the high blood glucose levels occurring in our experiments after calcium treatment were probably not related to an increase in gluconeogenesis. In response to the rise in both blood calcium and glucose, the reduced circulating levels of insulin probably increased, whereas glucagon decreased. In such conditions, a glycogenic effect should be observed. However, that was not the case since ${ }^{14} \mathrm{C}$-glucose incorporation decreased in the liver. Available evidence suggests that calcium enhances glycogenolysis by acting on phosphorylase, an enzyme which was shown to be calcium-sensitive in vitro (Keppens et al., 1977 ; Van de Werve ef al., 1977). Thus, our results support the view that parathyroid hormone or vitamin $D_{3}$ metabolites might act in two different ways : (i) by restoring the plasma calcium levels to normal, the calcium per se being partly the cause of the normoglycemia; (ii) by inhibiting the glycogenolytic effect of calcium and raising hepatic glycogen stores.

Using a low phosphorus diet we normalized the blood glucose level and also greatly increased hepatic glycogen siores in both mothers and fetuses. This finding on 
hepatic glycogen levels contrasts with those obtained with the calcium-rich (1.8 p. 100) diet containing a normal phosphorus level (0.6 p. 100). Fetal weight was also markedly improved by the low phosphorus diet given to TPTX mothers. The results obtained by this diet mimicked those observed after injection of 1,25-dihydroxyvitamin $D_{3}$ to TPTX mothers (Garel, Gilbert and Besnard, 1979). Our data agree with previous findings since TPTX rats placed on a low phosphate diet can amplify their production of 1,25-dihydroxyvitamin $D_{3}$ (Tanaka and de Luca, 1973) and augment total circulating 1,25-dihydroxyvitamin $\mathrm{D}_{3}$ fivefold (Hughes ef al., 1975). One interesting finding in the group on the low phosphorus diet was the high plasma phosphate maintained by the fetus when maternal phosphate level was extremely low.

Reçu en mars 1981.

Accepté en mai 1981.

Acknowledgements. - This work was supported by a grant from the Institut National de la Santé et de la Recherche Médicale (ATP 56-78-88, contract No 5).

Résumé. II a été montré précédemment que la glycémie et les réserves en glycogène sont profondément diminuées chez la ratte thyro-parathyroïdectomisée (TPTX) et ses fœtus, et que l'injection de métabolites de la vitamine $D_{3}$ permet de corriger ces effets en présence d'une calcémie maternelle basse bien qu'augmentée. Pour mieux évaluer le rôle éventuel du calcium dans ces expériences, on a dans le présent travail administré de manière aiguë ou chronique du calcium chez la ratte TPTX.

L'ingestion de glucose à 21,5 jours de gestation chez la ratte TPTX entraîne 4 h après une augmentation des réserves en glycogène hépatique à la fois chez la mère et le fœíus. De plus, l'incorporation de glucose ${ }^{14} \mathrm{C}$ dans le glycogène hépatique de la mère et du fotus est augmentée. Or, l'administration simultanée à la ratte TPTX de calcium et de glucose à 21,5 jours est suivie $4 \mathrm{~h}$ après d'une augmentation très importante de la glycémie maternelle et fœtale sans que les réserves en glycogène de la mère et du fotus ne soient modifiées. Au contraire, l'incorporation de glucose ${ }^{14} \mathrm{C}$ dans le glycogène hépatique du foetus est diminuée. Des résultats similaires sont obtenus par le traitement chronique de la ratte TPTX, qu'il s'agisse d'une supplémentation en lactate de calcium ou de l'administration d'un régime riche en calcium. Dans ces deux cas, les glycémies maternelles et fœtales font retour à la normale, mais les réserves en glycogène hépatique ne sont pas affectées que ce soit chez la mère ou le foetus. Au contraire, l'utilisation d'un régime pauvre en phosphore (situation qui est connue pour augmenter le taux de production de 1,25-dihydroxycholécalciférol) chez la ratte TPTX permet d'augmenter très nettement les réserves en glycogène hépatique chez la mère ef le fotus et de normaliser les glycémies maternelles et fœtales.

Ces résultats semblent suggérer que le 1,25-dihydroxycholécalciférol pourrait agir dans nos expériences de la manière suivante : - en augmentant la calcémie, ce qui expliquerait en partie l'augmentation de la glycémie ; - d'autre part la présence du 1,25dihydroxycholécalciférol s'opposerait à l'effet glycogénolytique du calcium permettant ainsi la mise en réserve du glycogène.

\section{References}

CHAN T. M., EXTON J. M., 1976. A rapid method for the determination of glycogen content and radioactivity in small quantities of tissues or isolated hepatocytes. Analyt. Biochem., 71, 96-105.

CHEN P. S., TORIBARA T. Y., WARNER H., 1956. Microdetermination of phosphorus. Analyt. Chem., 28, 1756-1758. 
FOURNIER P., 1954. Aperçus nouveaux sur la physiologie des glucides déduits de leur activité différente vis-à-vis de l'utilisation du calcium. C. R. Acad. Sci. Paris, Série D, 239, 718-720.

GAREL J.-M., 1969. Action hypocalcémiante et hypophosphatémiante de la thyrocalcitonine chez le rat avant ef après la naissance. C. R. Acad. Sci. Paris, Série D, 268, 1525-1528.

GAREL J.-M., GILBERT M., 1978. Rôle des parathyroïdes maternelles et des métabolites de la vitamine $D_{3}$ dans la croissance fotale et la mise en réserve du glycogène dans le foie maternel et foetal chez le rat. C. R. Acad. Sci., Paris, Série D, 286, 1459-1461.

GAREL J.-M., GILBERT M., BESNARD P., 1979 . Effects of vitamin $D_{3}$ metabolite injections into thyroparathyroidectomized pregnant rats on fetal weight and liver glycogen stores in mothers and fetuses, 271-274. In NORMAN A. W., SCHAEFER K., HERRATH D. V., GRIGOLEIT H. G., COBURN J. W., DE LUCA H. F., MAWER E. B., SUDA T., Vitamin D basic research and its clinical application, De Gruyter, Berlin.

GAREL J.-M., GILBERT M., BESNARD P., 1981. Fetal growth and 1,25-dihydroxyvitamin $D_{3}$ injections into thyroparathyroïdectomized pregnant rats. Repr. Nutr. Dévelop., 21, 961-968.

GILBERT M., BESNARD P., GAREL J.-M., 1980. Effects of maternal parathyroid glands and vitamin $D_{3}$ metabolites on fetal growth and fetal liver glycogen stores in thyro-parathyroidectomized pregnant rats. Biomedicine, 32, 93-99.

HRUSKA K. A., BLONDIN J., BASS R., SANTIAGO J., THOMAS L., ALTSHELER P., MARTIN K., KLAHR S., 1979. Effect of intact parathyroid hormone on hepatic glucose release in the dog. J. clin. Invest., 64, 1016-1023.

HUGGETT A. S. G., NIXON D. A., 1957. Use of glucose oxidase, peroxidase, and O-dianisidine in determination of blood and urinary glucose. Lancet, 2, 368-370.

HUGHES M. R., BRUMBAUGH P. F., HAUSSLER M. R., WERGEDAL J. E., BAYLINK D. J., 1975. Regulation of serum 1,25-dihydroxy vitamin $D_{3}$ by calcium and phosphate in the rat. Science, $190,578-580$.

KEPPENS S., VANDENHEEDE J. R., DE WULF H., 1977. On the role of calcium as second messenger in liver for the hormonally induced activation of glycogen phosphorylase. Biochem. biophys. Acto, 496, 448-457.

LENGEMANN F. W., WASSERMAN R. H., COMAR C. L., 1959. Studies on the enhancement of radiocalcium and radiostrontium absorption by lactose in the rat. J. Nufr., 68, 443-456.

MOXLEY M. A., BELL N. H., WAGLE S. R., ALLEN D. O., ASHMORE J., 1974. Parathyroid hormone stimulation of glucose and urea production in isolated liver cells. Am. J. Physiol., 227, 1058-1061.

PORTERFIELD S. P., WHITTLE E., HENDRICH C. E., 1975. Hypoglycemia and glycogen deficits in fetuses of hypothyroid pregnant rats. Proc. Soc. exp. Biol. Med., 149, 748-753.

ROEHRIG K. L., ALLRED J. B., 1974. Direct enzymatic procedure for determination of liver glycogen. Analyt. Biochem., 58, 414-421.

TANAKA Y., DE LUCA H. F., 1973. The control of 25-hydroxyvitamin D metabolism by inorganic phosphorus. Arch. Biochem. Biophys., 154, 566-574.

VAN DE WERVE G., HUE L., HERS H. G., 1977. Hormonal and ionic control of the glycogenolytic cascade in rat liver. Biochem. J., 162, 135-142. 